\title{
Analysis on the Path of Ideological and Political Education and Popularization of Marxism in Colleges and Universities
}

\author{
Yang Chu \\ Heilongjiang University, Harbin 150080, Heilongjiang, China \\ Email:29274812@qq.com
}

\begin{abstract}
Marxism, as the belief and direction of the Chinese people in direction, has never been an empty slogan. Marxism has always been full of vitality on the path of China's social development for people's prosperity and the rejuvenation of the Chinese nation. The nature in practise and popularity of Marxism put forward the internal requirements for the popularization of the theory. On the way of practicing Marxism, the Chinese people have always attached importance to the connection between theory and the public, closely integrating scientific theory with national development and people's life, which integrated theory into daily life in various ways to facilitate understanding and serve the public. In the new period, China has ushered in the great historical period of realization of national rejuvenation. Embracing the new situation, new problems and new demands, how to continue to adhere to the popularization of Marxism has become an important subject, which is worth in-depth and extensive discussion. As the cradle of talent training, colleges and universities shoulder the important task of supplying qualified talents for socialist construction. By analysis the value of the ideological education to Marxism in popularization to discuss the problems of the popularization of Marxism in the ideological and political education in colleges and universities, which can help us improve the understanding of the popularization of Marxism in colleges and universities, so as to explore the ideological and political education and the realization of the popularization of Marxism.
\end{abstract}

Keywords: colleges and universities, ideological and political education, Marxism, popularization, path

\section{Introduction}

Since the spread of the flame of Marxism in China, the Chinese society, under the guidance of Marxism, has gone through many difficulties and become prosperous and democratic in a incremental manner. The history of China's development has proved that Marxism is scientific and advanced, but what really makes Marxism be rooted and grow in China is its mass character and practicality. The popularization of Marxism, as a concrete embodiment of the mass and practicality of Marxism, has always been attached importance to by the Party and the state. As early as in the Yan'an period, Mao Zedong put forward the issue of giving top priority to the popularization of Marxism, opposing the eight-party ideology, and being alert to the phenomenon of theory separating from the masses. Entered the new period, Xi Jinping, the general secretary, have pointed out that the popularization of Marxism to a new era in China's development with emphasis on "upholding and developing socialism with Chinese characteristics in the new era, a large number of good talents who can tell good history of Marxism that people can understand with willingness so as to enable the innovative theory be utilized in people's daily life. The popularization of Marxism in the new period should be given more attention to the connection between the excavation of the connotation of scientific theory and the life of the masses, well perceived and vivid expressions closely connected to the public can be used to tell the history of Marxist theory, so that the masses can feel the guiding role of the theory on life, as a result, the masses will show their willingness to learn Marxism and use Marxism and believe in Marxism spontaneously.

\section{Analysis of significance in promoting ideological and political education in colleges and universities and popularization of Marxism}

\subsection{Promotion of the popularization of Marxism is the task of ideological and political education in colleges and universities in the new era}

In the new era, China witnessed soaring development of economy. With the improvement of people's living standards, people's demand for spiritual culture is unprecedentedly high. The collision of schools of thought at home and abroad is increasingly approaching cutting-throat stage, and the alternation of old and new ideas can easily cause various social contradictions. As the base of talent training and the position of ideological construction, colleges and universities shoulder 
the important task of cultivating outstanding young talents for our country. It is the historical mission entrusted by the times for colleges and universities to firmly establish Marxist belief among intellectuals to guide young people to pursue Marxism in life and strive for the great rejuvenation of the Chinese nation. As a combination of scientific world outlook and methodology, Marxism's scientific theory is forward-looking and instructive. In the new period, colleges and universities should conform to the needs of the development of the times and develop and inherit Marx well. It is the task of ideological and political work in colleges and universities to put the popularization of Marxism into practice, to transfer the connotation of scientific theory in a form that is easy for young people to understand, as a result, young people can be guided to correctly understand the development of the times and to develop the correct view of the collision of ideas for resolution of social contradictions.

\subsection{Promotion of the popularization of Marxism is the internal requirement for colleges and universities to carry out ideological education in the new era}

Ideological and political engagement has always been one of the key tasks in universities. Faced with various new situations in the new period, how to adhere to and develop Marxism has become a problem that needs to be given attention and discussion from all walks of life. There are many problems in the mode of ideological and political work in colleges and universities centering on theoretical propaganda. The effect of ideological and political work in colleges and universities is affected by the slow construction and renewal of ideological and political curriculum system, the outdated ideological and political education mode, and the low subjectivity and participation of teachers and students. To promote the popularization of Marxism is to integrate fresh Marxism into the work and life of teachers and students. On the one hand, promotion of the popularization of Marx's theory is conducive to the ideological and political engagement of colleges and universities to transform the theoretical language into a life language for easy understanding. On the other hand, through the popularization of Marxist practice, the ideological and political engagement in colleges and universities can effectively guide the learning object to appreciate the scientific nature of Marx in daily life, work and study, and deeply understand the theoretical connotation. The third aspect is that through the popularization of Marxism, the ideological and political work in colleges and universities can be better innovated. These aspects are in line with the internal requirements of ideological and political work in colleges and universities.

\subsection{Promotion of the popularization of Marxism is the purpose of talents building in colleges and universities in the new era}

The construction of socialism fails to be made without talents. In the new era, colleges and universities shoulder the important task of cultivating high-quality talents for the country. The premise to provides talented person to support for socialism is achieved with resolutions in minds. Young students are the hope of the country, only the theory is widely spread among the teachers and students and do a good job in the popularization of Marxism, advanced theory be rooted in the hearts of young people for inheritance of the ideal of Marxism, the high-quality talents that the motherland really needs can be cultivated. The mission of education is to cultivate talents and learn Marxist scientific theory well, which can not only answer people's perplexity on the national road, life development and value choice, it provides scientific research practice with scientific methodology so as to provide intellectual guarantee for students to become talents. Colleges and universities enjoys a natural advantage in making good use of talents and concentration of scientific researches. We should actively guide and cultivate a batch of talents with resolute ideas, scientific literacy quality, rich reserve of knowledge. Besides, we should start from the demands of the people and the society as a whole to have a in-depth research of the issues that the country and people concern. The construction of talents cultivation in universities and colleges fails to be achieved without talents with large reserve of knowledge and those with correct outlook on life. Marxism should be firmly in the mind of colleges students in all the stage, that is, the stage of career and life and the aim of contributing to enhancing the national strength and national cohesion is the ultimate goal of talent cultivation in colleges and universities.

\section{Problems in promoting the popularization of Marxism in college ideological and political education}

\subsection{Ideological and political courses in universities should pay more attention to promoting the popularization of Marxism}

Ideological and political engagement in universities is first reflected in the arrangement of ideological and political courses. Ideological and political curriculum in colleges and universities is the concentrated embodiment of the theoretical 
research level and education level, and the establishment of ideological and political curriculum system directly affects the teaching direction and effect of this course. As the main channel of ideological and political education in colleges and universities, the rich and complete ideological and political curriculum system should have a clear educational goal of Popularization of Marxism, and at the same time, it should be reflected in the curriculum arrangement. The current curriculum arrangement in ideology and politics in colleges and universities is destitute of the popularization of Marxism, without clear goal in education and empty expressions should not be used in interpret Marxism Although that Marxism plays an important role in solving social problems, it fails to highlight the purpose to achieve popularization of Marxism.

\subsection{The teaching level of teachers for ideological and political in popularization of Marxism in colleges and universities needs to be improved}

Ideological and political teachers in colleges and universities are an important force to carry out ideological and political work. Marxism plays an important guiding role in the development of society and life with its scientific nature. For young students, the outlook on life, values, world outlook are in the establishment stage of cultivation, on the one hand, young people are eager to understand the society, understand the development of things, one the other hand, young people are prone to develop wrong recognition for wrong values. The role of ideological and political engagement is to help students correctly understand the development of society and things, and guide the establishment of Marxist scientific concepts. The popularization of Marxism in the new period poses demanding requirements for ideological and political teachers who are required to grasp the spiritual needs of the youth, at the same time, teachers should master higher teaching skills in Marxism education to enhance political education in colleges and universities teachers teaching level of the popularization of Marxism. Besides, expressions commonly used by students in daily life can be adopted to interpret Marxist thought.

\subsection{The youth as subjectivity in the popularization of Marxism in ideological and political courses in colleges and universities is not prominent}

Youth is the potential force of social development, the future of a country and the hope of a nation. Colleges and universities are the hub of young people. The object of the popularization of Marxism is to enable young people to know, understand and master advanced scientific Marxism. In the new era, with the popularization of science and technology, the sources of young people's thoughts are demonstrated with diversity, and various ideologies and ideas tend to continue to invade our their life, and their demand for ideology is obviously enhanced. At the same time, young people who grow up in a more comfortable and stable environment, have developed a relatively simple understanding of society, and tend to have a one-sided understanding of things. Facing these new characteristics, the ideological and political work in colleges and universities should be given more attention to the young generation. Especially in the popularization of Marxism, the young should be rendered as the main body. On the one hand, youth should be regarded as the main object of learning and spreading Marxism. On the other hand, we should pay more attention to the learning experience of youth and enrich the promotion methods and working methods from the perspective of young people.

\section{Analysis of ideological and political education and popularization of Marxism in colleges and universities}

\subsection{Improve the teaching concept and establish the concept to vigorously promote the popularization} of Marxism in the teaching of ideological and political courses in colleges and universities

Ideological and political courses serve as an important carrier of the dissemination of Marxist theory in colleges and universities and in order to do a good job in the popularization of Marxism, we need to improve the awareness of the popularization of Marxism. On the one hand, popularization of Marxism should be highlighted in the curriculum setting. Taking popularization of Marxism as the daily work goal of ideological and political education in colleges and universities to make it clear is helpful for teaching and research teams to carry out training and professional skills improvement, and also helpful to remind teachers to pay attention to exploring the realization method of popularization of Marxism in their daily work and study. Second, to improve the teaching concept, we need to sort out the teaching material system, find and accumulate the teaching material of the popularization of Marxism. The educational idea can not be separated from the implementation of concrete work to form practical results. It is important to sort out the teaching material system and accumulate the popular teaching material of Marxism in line with the development of The Times. Only with sufficient teaching materials can teachers carry out teaching ideas with ease. 


\subsection{Cultivate teachers' skills and build a team of teachers who master excellent teaching skills in Marxist popularization}

The effective development of ideological and political work in colleges and universities and the popularization of Marxism into practice are inseparable from excellent ideological and political teachers with professional skills. Ideological and political teachers are the cornerstone of ideological and political work in colleges and universities. Excellent ideological and political teachers need long-term training from the country and schools. First of all, we should cultivate the sense of mission of ideological and political teachers in colleges and universities. Teachers are engineers of the human soul. Ideological and political teachers are socialist gardeners. Ideological and political teachers in colleges and universities should first have firm Marxist belief and disseminate and carry forward Marxism with lofty sense of mission and responsibility. Only when their belief is firm can they continuously study on skills and have educational appeal. Secondly, ideological and political teachers in colleges and universities should be trained in their educational skills. Ideological and political teachers should actively study, constantly deepen the understanding and application of Marx's theory, and at the same time, we should pay attention to social development and understand the ideological needs of young people. To pay attention to life based education, variety of teaching materials and diversity of teaching means. Heuristic classroom teaching, project based teaching and collaborative discussions can be adopted with audio-video and movie based multimedia to create a teaching environment students can accept, as a result, students are guided to show willingness to learn Marxist theory in a active manner to do a good job in education of ideology and politics in colleges and universities and to achieve the goals of achievement of popularization of Marxist theory.

\subsection{Highlight the subject of youth and increase the link for subject experience and experience feedback around the audience}

In the new period, the popularization of Marxism in colleges and universities should be carried out closely around the main body of young people to create a good atmosphere for them to actively study Marxism and explore the development of the country and the nation. In light of highlighting the subject of youth, ideological and political teachers in colleges and universities are required to think about the issues concerned by youth from the perspective of youth. At the same time, we should guide young people to participate in political study by more diversified and modern means. Multimedia, network video, interactive games, animation and film can be used to attract the attention of young groups. Drawing lessons from the concept of game interaction, the teaching is interspersed with project practice, independent research, learning interaction and other ways to enhance the subject learning body, deepen the understanding of Marxism. Increase the feedback of learning experience, collect young subjects' understanding of Marxism learning, as well as suggestions for the popularization of Marxism. All these can effectively highlight the dominant position of youth and improve the learning effect of youth groups.

\section{Conclusion}

The popularization of Marxism is the internal requirement of Marxism in embodiment of mass character and practicality, which is the internal power of Marxism to maintain vitality and vitality in China. It is an effective way to strengthen the masses' belief in Marxism to popularize Marxism well and to integrate scientific theory into daily life and serve life. As the hub to cultivate talents, colleges and universities shoulder the responsibility of providing personnel guarantee for the development of socialism, and it is duty-bound to publicize Marxism and consolidate Marxist ideological position. Confronting the more complex situation at home and abroad in the new period, it is increasingly important to resist the influence of foreign ideological trends on young people and college students should be guided to learn Marxist theory well and establish a firm belief in Marxism. In the process of promoting Marxism education, ideological and political education bears the brunt. To explore how to combine the popularization of Marxism with the ideological and political education in colleges and universities, analysis can be conducted by us from three aspects, that is, colleges and universities, teachers and students. The overwhelming majority of teachers and students are encouraged to understand the value of promoting the ideological and political education in colleges and universities and the popularization of Marxism, and they should bear firm in mind the Marxist faith from the ideological and political education in colleges and universities and the popularization of Marxism. At the same time, summaries in the problems in the promotion of ideological and political education in colleges and universities and the popularization of Marxism should be conducted in a appropriate manner, which is conducive to exploring the realistic path of ideological and political education and popularization of Marxism in colleges and universities. 


\section{References}

[1] Xi Jinping. Speech at the Opening Ceremony of the Second Group of Advanced Classes in the Autumn Semester of 2009 at Party School of the CPC Central Committee[N]. Study Times, 2009-11-16.

[2] Collected Works of Marx and Engels: Volume 1[M]. Beijing: People's Publishing House, 2009.

[3] Selected Works of Mao Zedong: Volume 4[M]. Beijing: People's Publishing House, 1991.

[4] Luo Xucheng. Popularization of Marxism in colleges and universities: Understanding of its significance, task and regularity[J]. Higher Education and Economy, 2011;02.

[5] Zhou Sijia. Analysis on the path of promoting the popularization of Marxism in college ideological and political education[J]. New West, 2019;5.

[6] Xu Xueshan. Promotion of the Popularization of Marxism in college ideological and political education [J]. Modern Management, 2016;10.

[7] Li Xuyan. Ideological and political education in colleges and universities and promotion of the sinicization, epochization and popularization of Marxism[J]. Theoretical Front In Higher Education, 2011;06.

[8] Dai Yuliang, Lin Bo. Sinicization of marxism and ideological and political education[J]. New Curriculum, $2015 ; 08$.

[9] Chen Yiyong. Ideological and political education in colleges and universities must be guided by Marxist indoctrination theory[J]. Journal of Social Science of Jiamusi University, 2016;02.

[10] Lin Jianhua, NIE Xin. The combination of the latest Achievements of Marxism sinicization and ideological and political courses in colleges and universities[J]. Journal of Beihua University (Social Science Edition), 2016;02.

[11] $\mathrm{Hu}$ Wenjing. Discussion on the popularization education of Marxism in the ideological and political education in colleges and universities[J]. Journal of Jining Normal University, 2013;03.

[12] Li Xiaoguang. Strengthening the study of Marxist classics and promoting the discipline construction of ideological and political education[J]. Leading Journal of Ideological \& Theoretical Education, 2017;06.

[13] Gu Li. A probe into the innovation of Marxist "Three Modernizations" and ideological and political education of college students[J]. Insight, 2016;15.

[14] Li Jingjing. The integration and development of college students' ideological and political education and Marxism sinicization in the new era[J]. Think Tank Era, 2019;3. 